\title{
首都巻における木造軸組構法住宅の耐震性能に関する研究 STUDY ON SEISMIC PERFORMANCE OF JAPANESE CONVENTIONAL WOODEN HOUSES IN METROPOLITAN AREA IN JAPAN
}

\author{
大塚悠里 ${ }^{* 1}$, 五十田 博*2, 平石久廣*3 \\ Yuri OTSUKA, Hiroshi ISODA and Hisahiro HIRAISHI
}

\begin{abstract}
This paper evaluated the seismic response of Japanese conventional wooden houses, considering the site amplification effect. In the evaluation, the response analysis was performed focusing on the base shear coefficient as a variable. From the time history analytical results, it was proved that the seismic performance of wooden houses was significantly influenced by the site amplification. And the paper investigated this influence from the viewpoint of the acceleration response spectrum and equivalent period. Finally, the paper presented the damage estimation map of the wooden houses classified into five categories based on the drift angle of the analytical results.
\end{abstract}

Keywords : Japanese conventional wooden house, Earthquake response analysis, Site amplification effect, Seismic performance evaluation, Equivalent period 木造軸組構法住宅, 地震応答解析, 地盤増幅特性, 而震性能評価, 等価周期

\section{1. はじめに}

木造住宅は関東地震（1923 年）、宮城県沖地震（1978 年）、兵庫 県南部地震（1995 年）、近年では熊本地震（2016 年）などで甚大な 被害を被っている。このうち、関東地震の多くは火災などによる被 害とされているが、千葉県の館山などの震動によりほぼ全壊した地 域が報告されており、都心においても同様な震動による被害が発生 し、それが火災を誘引した大きな要因とも考えられる。また、兵庫 県南部地震では震度 7 の一部の地域において震動により壊滅的な被 害が生じている。

これらの震動による被害の大きな要因は、主に建物の耐力不足で あり、その改善のため壁量を増やすことなど大きな耐震規定の改定 がなされてきた。しかしながら、熊本地震において大きな被害を生 じた益城町では、性能表示の耐震等級 2 の木造建物でも大きな被害 が生じた例があること、及び地盤や地形の異なる地域での住宅被害 率に大きな差異があることが報告されている 1)。

このうち地盤の影響については、木造住宅の多くが仕様規定で造 られているため、実質的には耐震設計に考慮されていないと言える。 また、木造以外の建物において、いわゆる新耐震では、地盤の影響 が振動特性係数に取り入れられているものの、低層建物ではその影 響は実質的には反映されない。一方、限界耐力計算では低層建物に おいてもその影響が大きいことが報告されている22。

このため、著者等は現在広く用いられている保有水平耐力計算に より耐力を設定した鉄筋コンクリート造建物及び鉄筋コンクリート 造壁式構造を対象に、実地盤の地盤増幅を考慮した地震動を用いた
応答解析を行い、第 2 種地盤及び第 3 種地盤では、同じ地盤種に分 類される地盤であっても、上部構造の最大応答変形角が地盤ごとに 大きくばらつくことを明らかにしている。また、特に変形能に乏し い低層建物では、第 2 種地盤及び第 3 種地盤に分類される地域で建 物の限界層間変形角を超える可能性が大きいことを示している ${ }^{3), 4)}$

このような背景から、本論文では、我が国の代表的な住宅様式で ある木造軸組構法住宅を対象とし、地盤の影響を考慮した耐震性の 評価を行った。具体的には、首都圈の各地の実地盤情報（K-NET） を考慮した地震動を用い、木造軸組構法住宅を対象に地震時応答解 析を行った。また、応答解析より得られた結果を用いて、首都圈の 現行耐震基準による木造軸組構法住宅の耐震性の評価と災害想定マ ップを提示した。

なお、本論文のように首都圈の各地の実地盤情報を考慮した地震 動を用いて木造建物の耐震性を系統的かつ広範囲に検討した研究は 例を見ず、本例のような検討は防災上の観点からも意義あることと 考える。

\section{2. 解析概要}

本論文の検証に用いる解析モデルの概念図を Fig.1 に示す。解析 対象は、解放工学的基盤上の複数層からなる表層地盤上に建つ木造 軸組構法住宅である。

文献 3), 4) と同様に、解放工学的基盤における入力地震動には、平 12 建告第 1461 号に示された「極めて稀に発生する地震動」の加速 度応答スペクトルに対応する模擬地震動（Fig.2 参照）を入力した。
*1 国立研究開発法人建築研究所 博士 (工学)

*2 京都大学生存圈研究所 教授・博士 (工学)

*3 明治大学理工学部建築学科 名誉教授. 工博 国立研究開発法人建築研究所 客員研究員
Building Research Institute, Dr.Eng.

Prof., Research Institute for Sustainable Humanosphere, Kyoto Univ., Dr.Eng.

Prof. Emer., Dept. of Architecture, School of Science and Technology, Meiji Univ., Dr.Eng. /

Visiting Research Fellow, Building Research Institute 
なお、本論文では、地盤の増幅特性による影響を考慮するため、文 献 ${ }^{5)}$ より、解放工学的基盤に入力寸る地震動の位相特性は乱数位相 とし、包絡関数は Fig.2 のように特定の周波数で大きく変動しない ものを用い、継続時間 120 秒とした。

表層の地震動は首都圈各地の地盤情報を基に、解放工学的基盤の 地震動に地盤増幅を反映することで解析的に算出した。具体的な算 出方法は、文献 ${ }^{3), 4)}$ と同様に、以下の条件の下、等価線形一次元地盤 応答解析プログラムSHAKE を用いて求めた。

・地盤情報には、防災科学研究所強震ネットワーク（K-NET）に 公開されているデータ（118 カ所）を用いた。

・土状図を参考に、士質は砂質土と粘性土の 2 種類とした。

・ せん断波速度が $400 \mathrm{~m} / \mathrm{s}$ 以上の層が $5 \mathrm{~m}$ 以上に渡って続いてい る場合は、その層を解放工学的基盤とした。

・上記に該当する層がない場合は、最深である深度 $20 \mathrm{~m}$ を解放 工学的基盤の上部とした。

・地盤の非線形モデルは Hardin - Drnevich model ${ }^{6}$ とした。

・基準せん断歪み $\gamma_{0.5}$ は、砂質土で $0.10 \%$ 、粘性土で $0.18 \%$ とし た $^{7)}$ 。

- 最大減衰定数 $h_{\max }$ は、砂質土で $21 \%$ 、粘性土で $17 \%$ とした 7 。 なお、解析時に地盤のひずみレベルが $1 \%$ を超える解析地点では、 直接積分法による時刻歴非線形解析により表層の地震動を算出した。 また、地盤の液状化については、本論文では今後の課題とし、考慮 しないものとした。

地盤の 1 次卓越周期 $T_{\text {、 }}$ 地盤種別及び解析地点名を Table 1 に示 す。また、Fig.3 に本論文で用いた防災科学研究所強震ネットワーク (K-NET)による解析地点を示寸。なお、各地盤の種別判定は、(1)式 $\sim(3)$ 式により求め 7$)$ 、地盤の 1 次卓越周期 $T_{I}$ の算定には、文献 ${ }^{8)}$ 参考とした。

$$
\begin{array}{ll}
{[1 \text { 種地盤 }]} & T_{1} \leq 0.2 \\
{[2 \text { 種地盤 }]} & 0.2<T_{1} \leq 0.75 \\
{[3 \text { 種地盤 }]} & 0.75<T_{1}
\end{array}
$$

上部構造は、表層地盤上の木造軸組構法住宅とした。階数は 2 階 建てとし、2 質点化して検討を行った。復元力特性は文献 9)を参考
に、木造軸組構法住宅の挙動をよく再現できているとされる bilinear+slip モデルとした(Fig.4)。各折れ点耐力及び折れ点間剛性は(4) 式〜(10)式により求めた。なお、実際の木造住宅では、1/20(rad.)以降 の耐力は低下寸ることが多いが、本論文では考慮していない。これ は本論文の検討が、設計用の地震動に対して、設計の限界変形角 $R_{u}$ $(=1 / 30$ ( rad. $))$ に対し 1.5 倍の余裕度 7)で、評価では破壊 ${ }^{10)}$ と見做 される $1 / 20(\mathrm{rad}$.)以降を倒壊と見做し、それを超える応答変形に特段 の意味がないことによる。
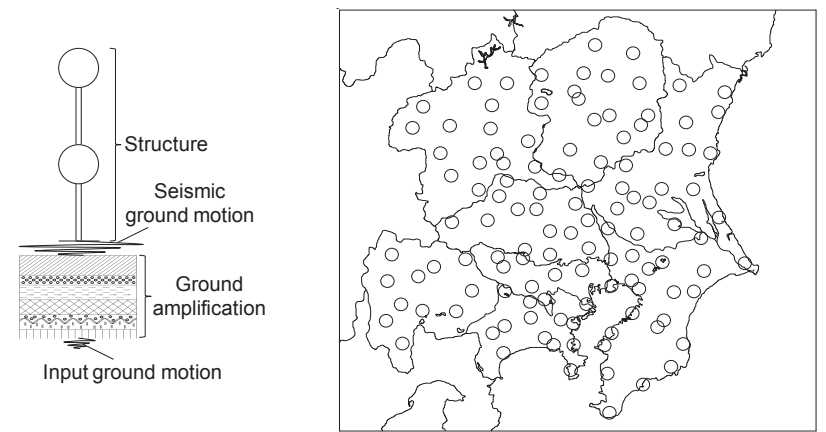

Fig.1 Concept of analysis

Fig.3 Site location analysis

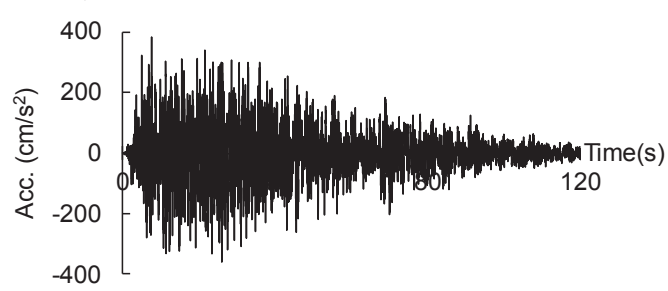

(a) Time history waveform

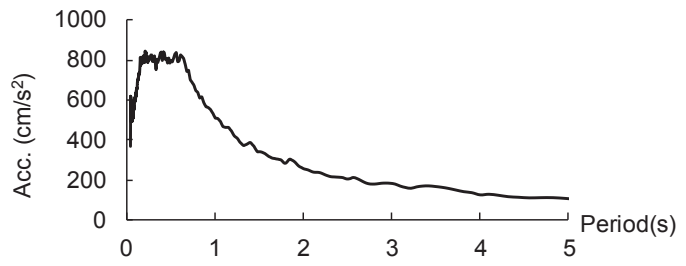

(b) Acceleration response spectrum

\begin{tabular}{|c|c|c|c|c|c|c|c|c|c|c|c|c|c|c|c|c|c|c|c|}
\hline $\begin{array}{c}\text { Prefecture } \\
\text { name } \\
\text { name }\end{array}$ & Site class & Analysis location & \begin{tabular}{|c}
$\begin{array}{c}\text { Primary period } \\
\text { (sec.) }\end{array}$ \\
\end{tabular} & $\begin{array}{c}\begin{array}{c}\text { Prefocture } \\
\text { name }\end{array} \\
\end{array}$ & Site class & Analysis location & \begin{tabular}{|c|}
$\begin{array}{c}\text { Primary period } \\
(\mathrm{secc})\end{array}$ \\
\end{tabular} & $\begin{array}{c}\text { Prefecture } \\
\text { name }\end{array}$ & Sthe class & Analysis Iocation & 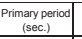 & $\begin{array}{c}\begin{array}{c}\text { Prefecture } \\
\text { name } \\
\end{array} \\
\end{array}$ & Site class & Analysis location & 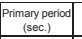 & $\begin{array}{c}\text { Prefecture } \\
\text { name } \\
\text { name }\end{array}$ & Sthe class & Analysis location & \begin{tabular}{|c|}
$\begin{array}{c}\text { Primary period } \\
\text { (sec.) }\end{array}$ \\
\end{tabular} \\
\hline \multirow{7}{*}{ Tokro } & \multirow[b]{2}{*}{1} & HIKAWA & 0.18 & \multirow{19}{*}{ CHBAA } & \multirow{3}{*}{1} & KATSUURA & 0.11 & \multirow{9}{*}{ SATAMA } & \multirow{7}{*}{2} & HoNNo & 0.27 & \multirow{3}{*}{ IBARAKI } & \multirow{3}{*}{2} & NAKAMNATO & 0.23 & \multirow{11}{*}{ GUNMA } & \multirow{7}{*}{1} & AGATSUMA & 0.16 \\
\hline & & HINOHARA & 0.13 & & & SHRAHAMA & 0.05 & & & KUMMGAYA & 0.31 & & & TORIDE & 0.22 & & & SHBUUKAWA & 0.19 \\
\hline & \multirow{5}{*}{2} & OUME & 0.44 & & & Futrsu & 0.20 & & & OGAWA (S) & 0.26 & & & KASHIMA & 0.21 & & & KRTU & 0.12 \\
\hline & & MACHIDA & 0.30 & & \multirow{13}{*}{2} & NODA & 0.38 & & & KASUKABE & 0.57 & \multirow{16}{*}{ TOCHGI } & \multirow{12}{*}{1} & KUROISO & 0.03 & & & ISESAKI & 0.19 \\
\hline & & SHINUKU & 0.30 & & & SHIROI & 0.50 & & & OHMYA(S) & 0.73 & & & SHIBAARA & 0.02 & & & SAKAMOTO & 0.05 \\
\hline & & НАСНIOJ & 0.23 & & & NARTA & 0.40 & & & TOKOROZANA & 0.34 & & & FUIMARA & 0.16 & & & SHMONTA & 0.04 \\
\hline & & KOGANEI & 0.24 & & & SAKURA & 0.37 & & & NAGATORO & 0.23 & & & Үимото & 0.11 & & & MAMBA & 0.09 \\
\hline \multirow{13}{*}{ KANAGAWA } & \multirow{6}{*}{1} & YoKosUKA & 0.10 & & & CHIBA & 0.67 & & \multirow{2}{*}{3} & KUKI & 1.37 & & & OGANA (T) & 0.13 & & \multirow{4}{*}{2} & MAEBASHI & 0.27 \\
\hline & & KAMAKURA & 0.11 & & & YOKACHIBA & 0.53 & & & KAWAGUCHI & 1.13 & & & UTSUNOMYA & 0.04 & & & TATEBAYASH & 0.39 \\
\hline & & FUTAMATAGAWA & 0.17 & & & HASUNUMA & 0.56 & \multirow{15}{*}{ IBARAKI } & \multirow{3}{*}{1} & TAKAAAGI & 0.17 & & & IMACHII (T-1) & 0.03 & & & OHTA & 0.31 \\
\hline & & FUINO & 0.07 & & & TOGANE & 0.38 & & & мто & 0.20 & & & KUZZU & 0.15 & & & TAKASAKI & 0.35 \\
\hline & & HADANO & 0.10 & & & ANEZAKI & 0.65 & & & SHMODATE & 0.04 & & & MOKA & 0.14 & \multirow{11}{*}{ YAMANASH } & & TABAYAMA & 0.03 \\
\hline & & YAMAKTA & 0.11 & & & KISARAZU & 0.67 & & \multirow{12}{*}{2} & HITACHI & 0.30 & & & MOTEGI & 0.15 & & & OHTSUKI & 0.19 \\
\hline & \multirow{5}{*}{2} & KAWASAKI & 0.72 & & & MSARI (C) & 0.63 & & & OHMYA(I) & 0.25 & & & SERNUMA & 0.10 & & & FWrrosHIDA & 0.13 \\
\hline & & FUISAWA & 0.31 & & & INAGE & 0.50 & & & KOGA & 0.38 & & & КПТТАКАOКА & 0.02 & & 1 & ENZAN & 0.15 \\
\hline & & MSAKI (K) & 0.21 & & & ICHBA & 0.43 & & & SHMOTSUMA & 0.45 & & \multirow{4}{*}{2} & YATA & 0.38 & & & MOTOSU & 0.07 \\
\hline & & SAGAMIHARA & 0.22 & & \multirow{3}{*}{3} & URAYASU & 0.99 & & & TSUKUBA & 0.45 & & & KANUMA & 0.31 & & & NANBU & 0.11 \\
\hline & & ATSUGI & 0.65 & & & KYONAN & 0.99 & & & ISHOKA & 0.69 & & & IMACH (T-2) & 0.31 & & & HAYAKAWA & 0.08 \\
\hline & 3 & ҮОКОНАМА & 1.12 & & & KAMOGAWA & 0.82 & & & НОКОТА & 0.28 & & & OYAMA & 0.22 & & & SUTAMA & 0.07 \\
\hline & & ODAWARA & 0.98 & & & CHCHВU & 0.08 & & & TSUCHURA & 0.30 & & & KATASHINA & 0.09 & & & KOFU & 0.51 \\
\hline & & Matsudo & 0.15 & & & HIGASHIIMATSUYAMA & 0.09 & & & WAI & 0.51 & & & MNAKAMI & 0.12 & & 2 & ROKUGO & 0.28 \\
\hline CHBA & 1 & SAWARA & 0.20 & SATAMA & 1 & KAMAGOE & 0.18 & & & EDOSAKI & 0.44 & GunMa & 1 & NUMATA & 0.13 & & & ASHIYASU & 0.41 \\
\hline 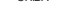 & & CHOSHI & 0.04 & & & HANNO & 0.04 & & & DAIGO & 0.23 & & & KUSATSU & 0.17 & & & & \\
\hline & & MOBARA & 0.04 & & & NAKATSUGAWA & 0.15 & & & KASAMA & 0.21 & & & TSUMAGOI & 0.17 & & & & \\
\hline
\end{tabular}

Fig.2 Input ground motion

Table1 Predominant period of the ground 


$$
\begin{gathered}
d_{1}=7.0 \times 10^{-4} \times h \\
P_{y}=C_{B} \times W_{u} \\
k_{b 1}=190.5 \times \frac{P_{y}}{h} \\
k_{b 2}=9.53 \times \frac{P_{y}}{h} \\
k_{s 1}=95.3 \times \frac{P_{y}}{h}
\end{gathered}
$$
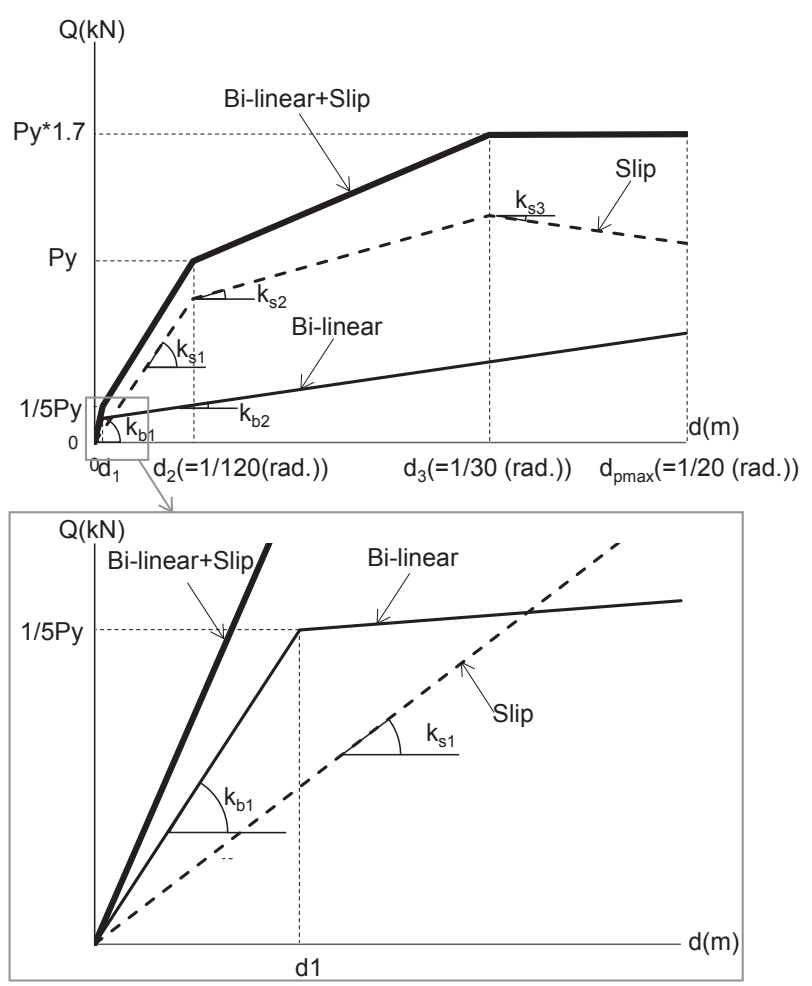

Fig.4 Q-ठ relationship of structure

Table2 Structural parameters

\begin{tabular}{|c|c|c|c|}
\hline Floor number & Each floor height $(\mathrm{m})$ & Each floor weight $(\mathrm{t})$ & $\begin{array}{c}\text { Fundamental } \\
\text { natural period }(\mathrm{s})\end{array}$ \\
\hline 1 & 2.8 & 30 & \multirow{2}{*}{0.17} \\
\hline 2 & 2.8 & 20 & \\
\hline
\end{tabular}

$$
\begin{aligned}
& k_{s 2}=18.34 \times \frac{P_{y}}{h} \\
& k_{s 3}=-9.24 \times \frac{P_{y}}{h}
\end{aligned}
$$

$$
h: \text { 階高 }(\mathrm{m})
$$

$P_{y}:$ 降伏荷重 $(\mathrm{kN})$

$C_{B}: 1$ 階の降伏耐力時ベースシア係数

$W_{u}:$ 各階重量 $(\mathrm{kN})$

なお、2 階の各折れ点耐力及び折れ点間剛性は、2 階の降伏耐力時 ベースシア係数 $C_{B 2}((11)$ 式)を(5)式の 1 階の降伏耐力時ベースシア係 数 $C_{B}$ （以下、ベースシア係数 $C_{B}$ ) に代入することで(6)式〜 (10)式に より算定した。

$$
C_{B 2}=C_{B} \times A_{i} \times 1.5
$$

ベースシア係数 $C_{B}$ をパラメータとし、 $0.1 、 0.2 、 0.4 、 0.6$ の計 4 種 類とした。なお、 3 種地盤のみベースシア係数 $C_{B}$ を 0.3 とした場合 の解析も行った。また、文献帛を参考に、上部構造の各層高さは $2.8(\mathrm{~m})$ とし、各層質量は 1 階を $30 \mathrm{t} 、 2$ 階を $20 \mathrm{t}$ とした。Table2 に上部構造 諸元を、Table 3 に算出した各折れ点耐力及び折れ点間剛性を示す。 なお、ベースシア係数 $C_{B}$ が 0.2 の場合を現行基準の木造軸組構法住 宅と見做している。ベースシア係数 $C_{B}$ が 0.6 の場合の木造軸組構法 住宅はほとんど建てられない建物であるが、ベースシア係数 $C_{B}$ が 0.4 の場合においても大きな被害がみられた（後述、3 章参照）こと から、無被害レベルの建物としてベースシア係数 $C_{B}$ が 0.6 の場合を 設定した。また、昭和 56 年（1981 年）以前の既存の木造住宅の平 均的な耐震診断評点が $0.5^{11)}$ ということを踏まえ、ベースシア係数 $C_{B}$ が 0.1 の場合を設定した。

また、限界層間変形角 $R_{u}$ については、木造軸組構法住宅の設計で 一般的によく用いられている 1/30(rad.)とした。

\section{3. 時刻歴解析結果}

以下には、2 章の方法により行った時刻歴応答解析結果を示す。 なお、 $1 / 20$ (rad.)以降の応答は以下で示寸応答より、実際ではより大 きな值となると考えられるが、大小の相対的な関係は合っているた め、以下では参考として $1 / 20(\mathrm{rad}$.$) 以降の応答も示す。$

Table3 Structural details

\begin{tabular}{|c|c|c|c|c|c|c|c|}
\hline \multirow{2}{*}{$C_{B}$} & Floor number & Py $(\mathrm{kN})$ & $k_{\mathrm{b} 1}(\mathrm{kN} / \mathrm{m})$ & $\mathrm{k}_{\mathrm{b} 2}(\mathrm{kN} / \mathrm{m})$ & $\mathrm{k}_{\mathrm{s} 1}(\mathrm{kN} / \mathrm{m})$ & $\mathrm{k}_{\mathrm{s} 2}(\mathrm{kN} / \mathrm{m})$ & \multirow{2}{*}{$\mathrm{k}_{\mathrm{s} 3}(\mathrm{kN} / \mathrm{m})$} \\
\hline \multirow{2}{*}{0.1} & 1 & 49.0 & 3333.8 & 166.8 & 1667.8 & 393.8 & -544.3 \\
\cline { 2 - 9 } & 2 & 37.2 & 2528.1 & 126.5 & 1264.7 & 298.6 & -412.7 \\
\hline \multirow{2}{*}{0.2} & 1 & 98.0 & 6667.5 & 333.6 & 3335.5 & 787.5 & -1088.5 \\
\cline { 2 - 9 } & 2 & 74.3 & 5056.1 & 252.9 & 2529.4 & 597.2 & -825.4 \\
\hline \multirow{2}{*}{0.3} & 1 & 147.0 & 10001.3 & 500.3 & 5003.3 & 1181.3 & -1632.8 \\
\cline { 2 - 9 } & 2 & 111.5 & 7584.2 & 379.4 & 3794.1 & 895.8 & -1238.2 \\
\hline \multirow{2}{*}{0.4} & 1 & 196.0 & 13335.0 & 667.1 & 6671.0 & 1575.0 & -2177.0 \\
\hline \multirow{2}{*}{0.6} & 1 & 148.6 & 10112.2 & 505.9 & 5058.8 & 1194.4 & -1650.9 \\
\cline { 2 - 9 } & 2 & 294.0 & 20002.5 & 1000.7 & 10006.5 & 2362.5 & -3265.5 \\
\hline
\end{tabular}




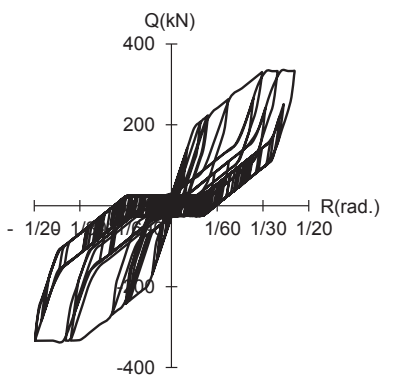

(i) 1 floor (ii) 2 floor

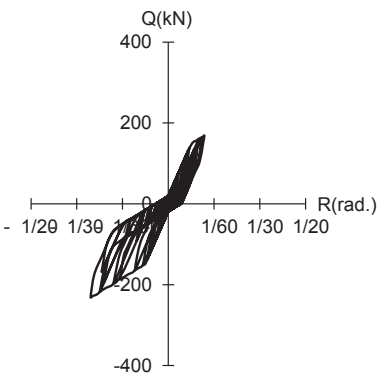

(a) KASUKABE

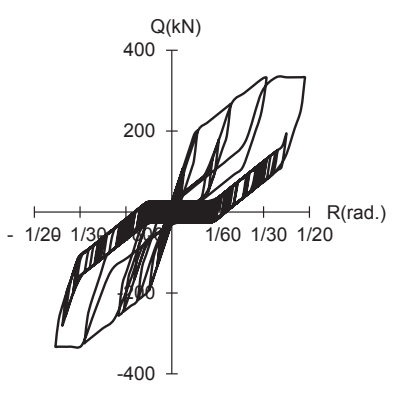

(i) 1 floor

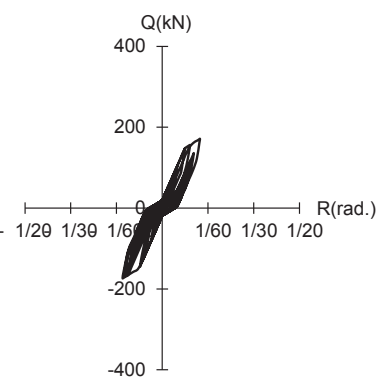

(ii) 2 floor (b) ANEZAKI

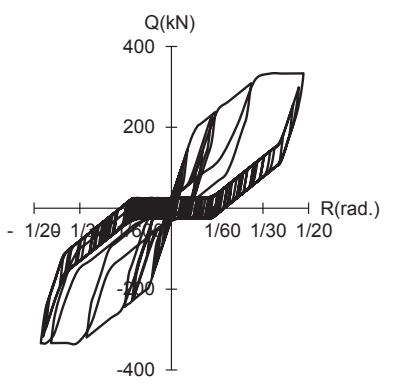

(i) 1 floor

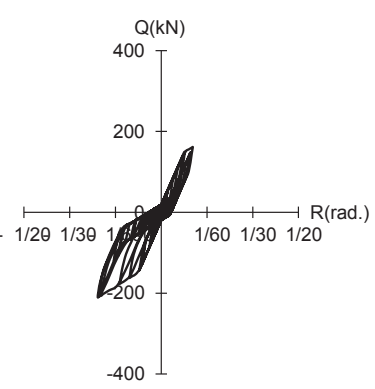

(ii) 2 floor (c) KYONAN

Fig.5 Q-R relationship of each floor

\section{1 時刻歴応答解析結果 (神奈川県)}

本節では、各解析地点における解析結果の詳細の一例として、神 奈川県における時刻歴応答解析結果を示す。

Fig. 5 にベースシア係数 $C_{B}$ が 0.4 の場合における層間変形角 $R$ と 層せん断力 $Q$ の関係を各層ごとに示す。なお、一例として、春日部 (2 種地盤)、姉崎（2 種地盤）、鋸南（3 種地盤）の結果を示す。

応答解析結果より、全ての解析地点において 2 階より 1 階の方が 大きい最大層間変形角 $R_{\max }$ を示した。そこで、Fig.6 に神奈川県にお ける 1 階の最大層間変形角をべースシア係数 $C_{B}$ ごとに示す。なお、 図中の実線は想定した大破に相当する変形角（以下：限界層間変形 角 $R_{u}$ と呼ぶ）である変形角 $1 / 30(\mathrm{rad}$.$) を示す。$

ベースシア係数 $C_{B}$ が 0.1 の場合、神奈川県における全ての解析地 点が限界層間変形角 $R_{u}(=1 / 30(\mathrm{rad})$.$) を超えた。$

ベースシア係数 $C_{B}$ が 0.2 の場合、 1 種地盤と 2 種地盤の相模原、 藤沢が限界層間変形角 $R_{u}$ 以下となった。一方、 2 種地盤の三崎、川 崎、厚木と 3 種地盤の小田原、横浜はベースシア係数 $C_{B}$ を 0.2 とし ても、限界層間変形角 $R_{u}$ を超える結果となった。

このうち、2 種地盤の川崎に至っては、ベースシア係数 $C_{B}$ を $0.4 、$

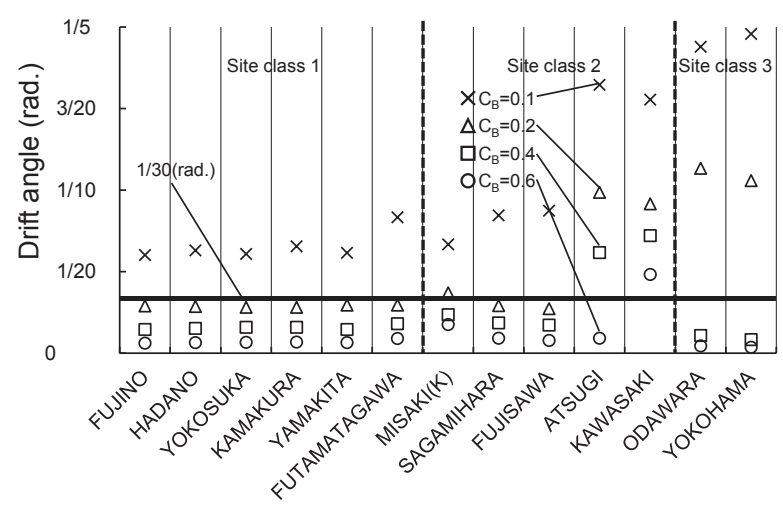

Fig.6 Maximum drift angle (KANAGAWA)

0.6 と増加しても、限界層間変形角 $R_{u}$ を超える結果となった。一方、 2 種地盤の厚木はベースシア係数 $C_{B}$ を 0.4 から 0.6 とした時、 2 種 地盤の三崎と 3 種地盤の小田原、横浜はベースシア係数 $C_{B}$ を 0.2 か ら 0.4 とした場合に、限界層間変形角 $R_{u}$ 以下となった。

\section{2 時刻歴応答解析結果（首都圏）}

本節では、3.1 節の応答解析結果（神奈川県）に加え、本論文で対 象とする首都圈の全解析地点における時刻歷応答解析結果を示寸。

Fig.7 にベースシア係数 $C_{B}$ 毎の時刻歴応答解析結果を、最大層間 変形角と地盤の 1 次卓越周期 $T_{1}$ の関係で示寸。なお、3.1 節と同様 に最大層間変形角はいずれの解析も 1 階の応答值により定まってい る。また、図中の実線は想定した限界層間変形角 $R_{u}$ である変形角 1/30(rad.)を、破線は上部構造の損傷が大きくなり始める目安とされ ている変形角 1/60（rad.）を示す。

ベースシア係数 $C_{B}$ が 0.1 の場合、全解析地点において最大層間変 形角が限界層間変形角 $R_{u}(=1 / 30(\mathrm{rad})$.$) を超える結果となった。$

ベースシア係数 $C_{B}$ が 0.2 の場合、 1 種地盤の全ての解析地点が限 界層間変形角 $R_{u}$ 以下となったが、損傷が大きくなり始める目安であ る変形角 $1 / 60$ (rad.)を超える結果となった。また、多くの 2 種地盤と 3 種地盤の解析地点が限界層間変形角 $R_{u}$ を超えた。

ベースシア係数 $C_{B}$ が 0.4 の場合、 1 種地盤のほとんどの解析地点 が変形角 $1 / 60$ (rad.) 以下を示した。また、2 種地盤のほとんどの解 析地点が限界層間変形角 $R_{u}$ 以下を示したが、一部の解析地点は大幅 に限界層間変形角 $R_{u}$ を超える結果となった。3 種地盤は川口、鋸南、 鴨川が限界層間変形角 $R_{u}$ を超えたが、浦安は限界層間変形角 $R_{u}$ 以 下となり、小田原、横浜、久喜に至っては大幅に応答が小さくなり、 変形角 $1 / 60$ (rad.) 以下の最大層間変形角を示した。特に、横浜に至 っては全解析地点の中でも最も小さな最大層間変形角の值を示した。 ベースシア係数 $C_{B}$ が 0.6 の場合、 1 種地盤は全ての解析地点が変 形角 $1 / 60$ (rad.) 以下を示した。2 種地盤はほとんどの解析地点が限界 層間変形角 $R_{u}$ 以下を示したが、川崎、白井、東金、姉崎、大子、甲 府は限界層間变形角 $R_{u}$ を超える結果となった。一方、青梅、厚木、 春日部、大宮、木更津、岬などの一部の 2 種地盤の解析地点は大幅 に応答が小さくなり、変形角 $1 / 60$ (rad.) 以下を示した。3 種地盤は鴨 川のみ限界層間変形角 $R_{u}$ を超える結果となったが、そのほかの解析 地点は限界層間変形角 $R_{u}$ 以下を示し、そのうち川口、浦安において は変形角 1/60（rad.）以下を示した。

ここで、Fig. 8 にベースシア係数 $C_{B}$ を 0.3 とした場合の結果を加 


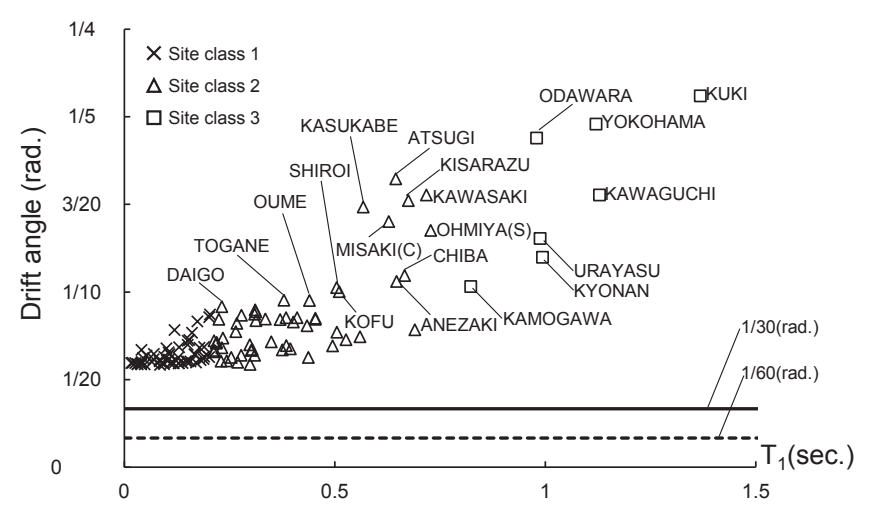

(a) $\mathrm{C}_{\mathrm{B}}=0.1$

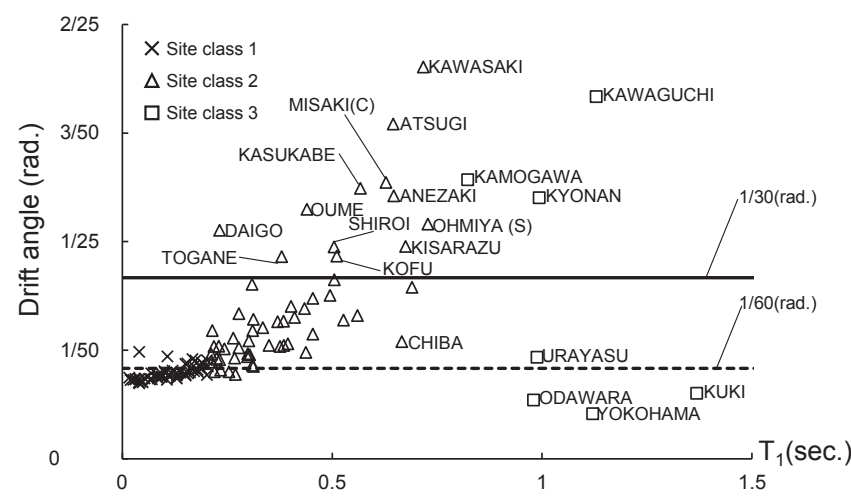

(c) $\mathrm{C}_{\mathrm{B}}=0.4$

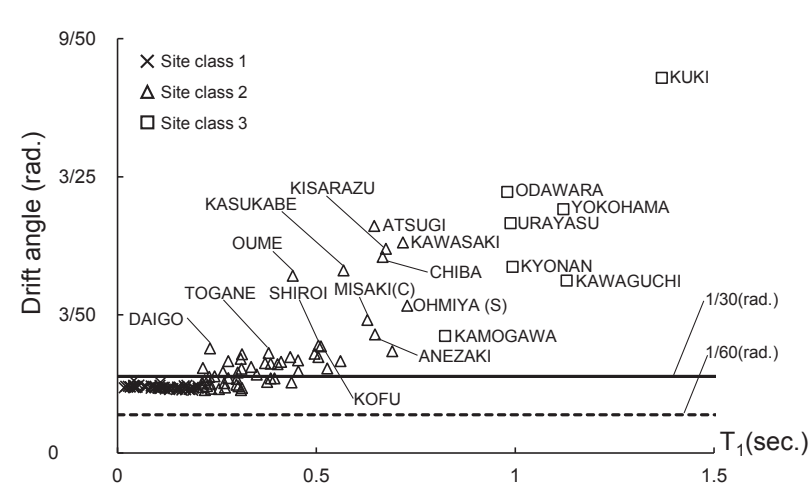

(b) $\mathrm{C}_{\mathrm{B}}=0.2$

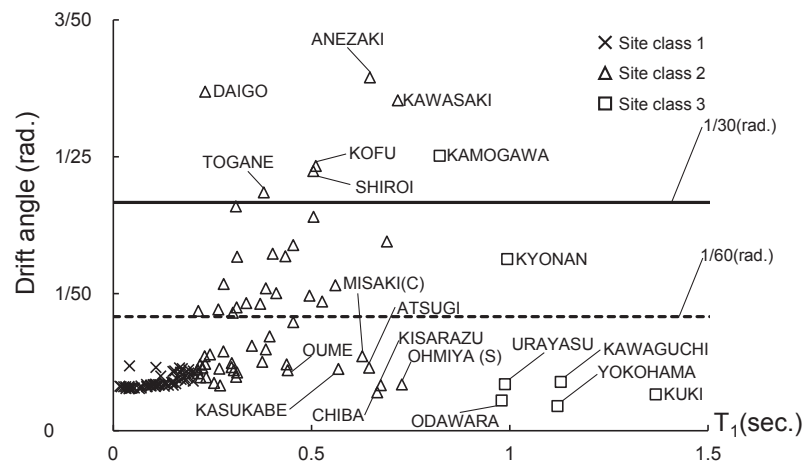

(d) $C_{B}=0.6$

Fig.7 $\mathrm{R}_{\max }-\mathrm{T}_{1}$ relations

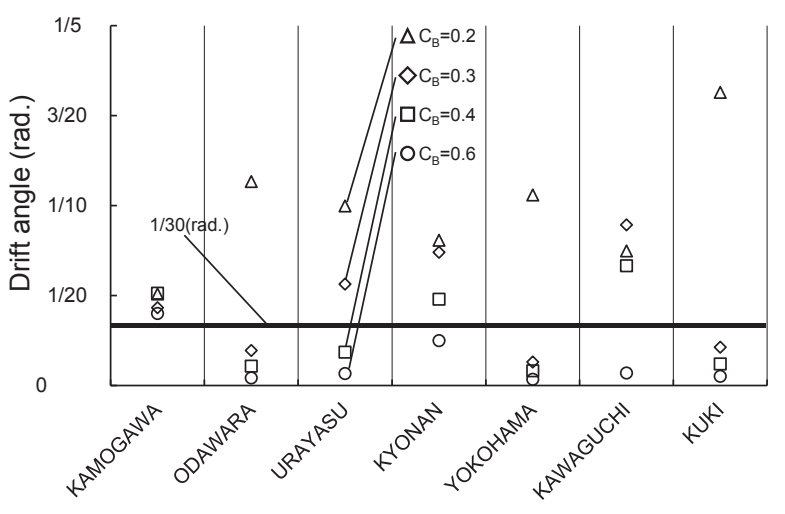

Fig.8 Maximum drift angle (Site class 3 )

えた 3 種地盤における応答解析結果を示す。なお、図中の実線は限 界層間変形角 $R_{u}$ である変形角 $1 / 30$ ( rad. ) を示す。小田原、横浜、 久喜はベースシア係数 $C_{B}$ を 0.2 から 0.3 とした場合に、限界層間変 形角 $R_{u}$ 以下の值を示した。また、浦安はベースシア係数 $C_{B}$ を 0.3 か ら 0.4 とした場合に、限界層間变形角 $R_{u}$ 以下の值を示した。さらに、 鋸南、川口は、ベースシア係数 $C_{B}$ を 0.4 から 0.6 とした場合に、限 界層間変形角 $R_{u}$ 以下の值を示した。一方、鴨川に至ってはベースシ ア係数 $C_{B}$ を変えても応答がほとんど変わらない結果となり、ベース シア係数 $C_{B}$ を 0.6 としても限界層間変形角 $R_{u}$ を超える結果となっ た。

3.1 節の神奈川県における応答解析結果と同様に 2 種地盤、3 種地
盤において、ベースシア係数 $C_{B}$ の值を上げても応答がさほじ小さく ならない解析地点がみられると共に、ベースシア係数 $C_{B}$ を大きくす ることで大幅に応答が小さくなる解析地点もみられ、同じ地盤種別 であってもその最大層間変形角には顕著な差異が生じた。

\section{3 最大応答時における等価周期と加速度応答スペクトルの関係}

本節では、3.1 節、3.2 節の同じ地盤種であってもべースシア係数 $C_{B}$ による影響が異なる現象について地盤の増幅特性と最大応答時 における等価周期の関係から考察を行った。

Fig.9 に各地盤種別から横須賀、鎌倉（1 種地盤）、川崎、三崎（神 奈川)、厚木、姉崎（2 種地盤）、横浜、鴨川（3 種地盤）の加速度応 答スペクトル $S_{a}$ を示す。なお、図中に破線で建物の等価周期 $T_{e q}$ を ベースシア係数 $C_{B}$ ごとに示す。また、ベースシア係数 $C_{B}$ ごとの初 期周期 $\left(d_{1}\right.$ の時の周期 $)$ を青の実線で示す。加速度応答スペクトル $S_{a}$ は文献 ${ }^{12)}$ を参考に、木造住宅が有する等価減衰定数として $15 \%$ を 仮定し、算定した。また、等価周期 $T_{e q}$ は応答解析結果を用いて、文 献 7)を参考に(12)式〜(17)式より算定した。なお、2 階の層間変形角

(正側) $R_{2}$ は、 1 階が最大応答変形角 (正側) を示寸時の 2 階の層 間変形角を示す。ベースシア係数 $C_{B}$ ごとの初期周期 $\left(d_{1}\right.$ の時の周 期）は(6)式、(8)式より、固有值解析により算出した。

$$
\begin{gathered}
\delta_{1}=R_{1} \cdot h \\
\delta_{2}=R_{2} \cdot h+\delta_{1} \\
Q=Q_{1}
\end{gathered}
$$




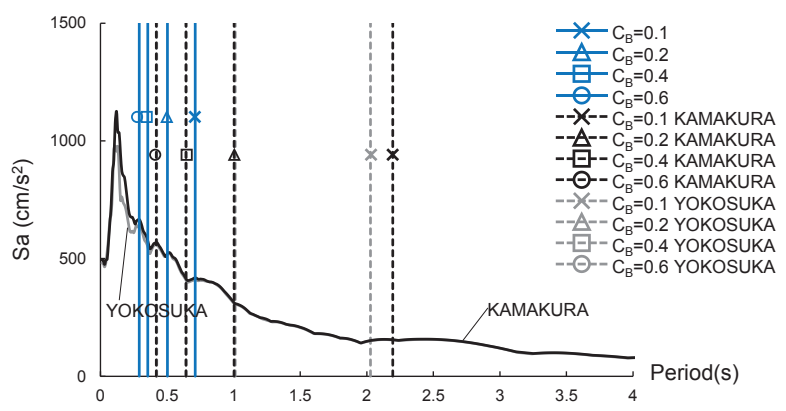

(a) Site class 1 (KAMAKURA, YOKOSUKA)

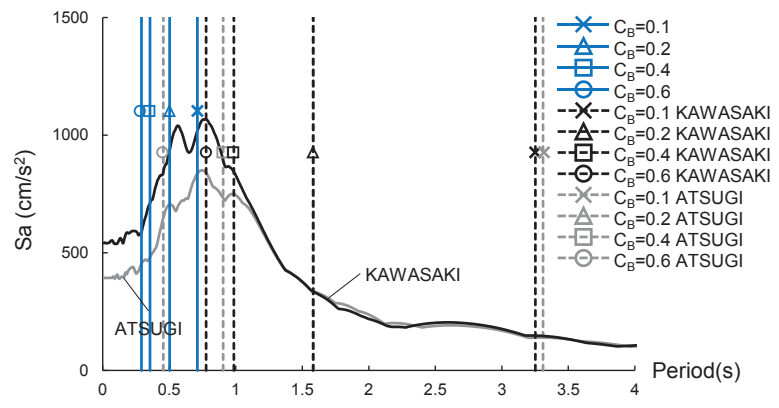

(c) Site class 2 (KAWASAKI, ATSUGI)

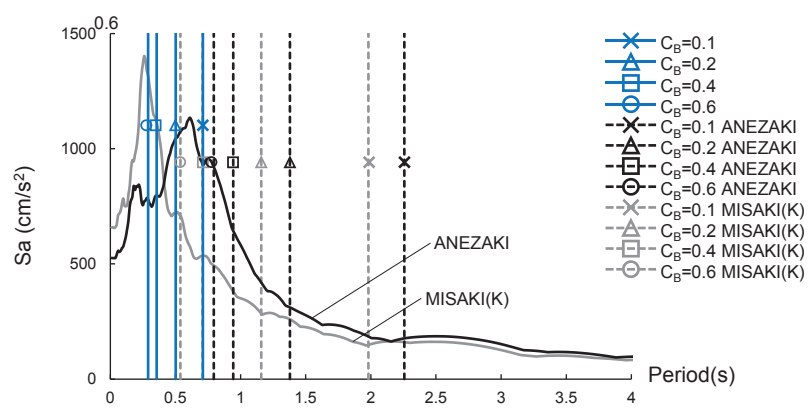

(b) Site class 2 (ANEZAKI, MISAKI(K))

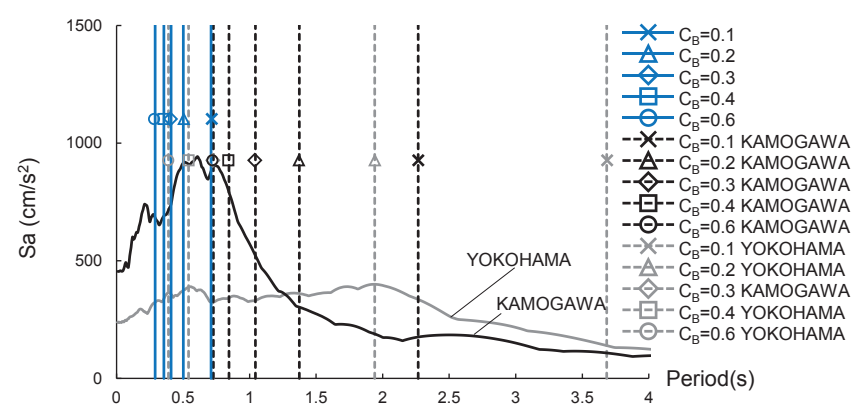

(d) Site class 3 (KAMOGAWA, YOKOHAMA)

Fig.9 Response acceleration spectrum and response periods at maximum response

$$
\begin{gathered}
M_{u s}=\frac{\left(m_{1} \cdot \delta_{1}+m_{2} \cdot \delta_{2}\right)^{2}}{m_{1} \cdot \delta_{1}^{2}+m_{2} \cdot \delta_{2}^{2}} \\
\Delta s=\frac{m_{1} \cdot \delta_{1}^{2}+m_{2} \cdot \delta_{2}^{2}}{m_{1} \cdot \delta_{1}+m_{2} \cdot \delta_{2}} \\
T_{e q}=2 \pi \sqrt{M_{u s} \frac{\Delta s}{Q}} \\
R_{1}: 1 \text { 階の最大層間変形角(正側) } \\
R_{2}: 2 \text { 階の層間変形角(正側) } \\
\left.m_{1}: 1 \text { 階の質量( } \mathrm{t}\right) \quad m_{2}: 2 \text { 階の質量 }(\mathrm{t}) \\
Q_{1}: 1 \text { 階の最大層せん断力(正側) }(\mathrm{kN})
\end{gathered}
$$

1 種地盤では解析地点によらず、ベースシア係数 $C_{B}$ ごとの建物の 等価周期 $T_{e q}$ がほぼ同じ值を示し、その值は各解析地点における地 盤の卓越周期（加速度応答スペクトル $S_{a}$ が最大值となる周期）より も長かった。初期周期も地盤の卓越周期を超えたところから始まっ ており、ベースシア係数 $C_{B}$ が 0.1 の場合を除いて最大応答変形は小 さくなる結果となった。

一方、2 種地盤では解析地点によって、ベースシア係数 $C_{B}$ ごとの 建物の等価周期 $T_{e q}$ もばらつく、つまり、応答変形に大きな差がでる 結果となった。また、ベースシア係数 $C_{B}$ が 0.6 でも最大層間変形角 が限界層間変形角 $R_{u}$ を超えた川崎、姉崎のベースシア係数 $C_{B}$ が 0.6 の時の等価周期 $T_{e q}$ と、ベースシア係数 $C_{B}$ が 0.4 の場合おいて限界 層間変形角 $R_{u}$ を超えた厚木のベースシア係数 $C_{B}$ が 0.4 の時の等価 周期 $T_{e q}$ は、各解析地点における地盤の卓越周期を超えており、いず れも初期周期と等価周期 $T_{e q}$ の間に地盤の卓越周期がある。さらに、 三崎（神奈川）の地盤の卓越周期は、川崎、厚木、姉崎より 0.5 秒
ほど短く、初期周期も地盤の卓越周期を超えている。その結果とし て、ベースシア係数 $C_{B}$ が小さくても最大層間変形角は小さくなっ た。

3 種地盤では、横浜のスペクトルはなだらかな形状で、つまり周 期 2 秒まで応答加速度の值が $400 \mathrm{~cm} / \mathrm{s}^{2}$ 程度で、ベースシア係数 $C_{B}$ が $0.1 、 0.2$ では、限界層間変形角 $R_{u}$ を超えた。一方で、ベースシア 係数 $C_{B}$ が 0.3 を超えると変形は限界層間変形角 $R_{u}$ 以下に留まった。 ベースシア係数 $C_{B}$ が 0.6 の場合でも最大層間変形角が限界層間変形 角 $R_{u}$ を超えた鴨川は、ベースシア係数 $C_{B}$ が 0.6 でも限界層間変形 角 $R_{u}$ を超えた川崎、姉崎（2 種地盤）及びベースシア係数 $C_{B}$ が 0.4 でも限界層間変形角 $R_{u}$ を超えた厚木（2 種地盤）とよく似たスペク トル形状を示した。なお、3 種地盤のうち、小田原、横浜、久喜のス ペクトルは良く似た形状を有しており、周期約 1 秒未満の領域の加 速度応答スペクトル $S_{a}$ の值が小さい。これらの解析地点では、Fig7 で示したように、ベースシア係数 $C_{B}$ が 0.3 の建物でも限界変形角 $R_{u}$ 以下の応答に留まっている。

上記のように、同じ地盤種別であっても、加速度応答スペクトル $S_{a}$ の形状が異なることが、応答に差異を生じた要因といえることか ら、次に加速度応答スペクトル $S_{a}$ と変位応答スペクトル $S_{d}$ 及び等 価周期 $T_{e q}$ の関係を用い、検討を深めた。

Fig10 に各地盤種別から横須賀、鎌倉（1 種地盤）、川崎、三崎（神 奈川）、厚木、姉崎（2 種地盤）、横浜、鴨川（3 種地盤）の加速度応 答スペクトル $S_{a}$ と変位応答スペクトル $S_{d}$ を示す。なお、文献 ${ }^{13)}$ り、木造建物は応答が小さい範囲でも $15 \%$ 程度の等価減衰定数を有 するため、変位応答スペクトル $S_{d}$ は加速度応答スペクトル $S_{a}$ と同 様に、等価減衰定数に $15 \%$ を用いて算定した。また、図中に黒の実 線で限界層間変形角 $R_{u}$ である変形角 $1 / 30 （ \mathrm{rad}$. ) を、灰色の実線で 変形角 $1 / 20$ (rad.) を示す。また、ベースシア係数 $C_{B}$ ごとの $S_{a} / S_{d}$ 


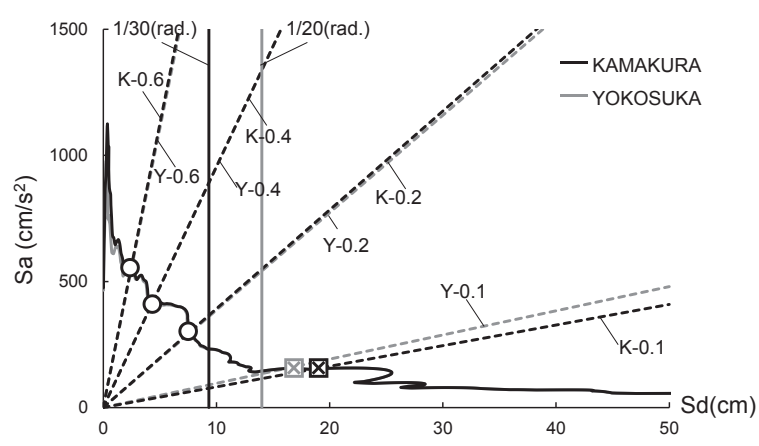

(a) Site class 1 (KAMAKURA, YOKOSUKA)

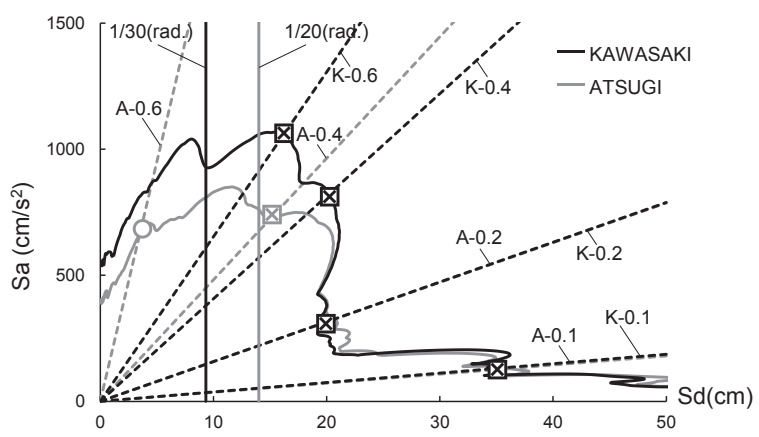

(c) Site class 2 (KAWASAKI, ATSUGI)

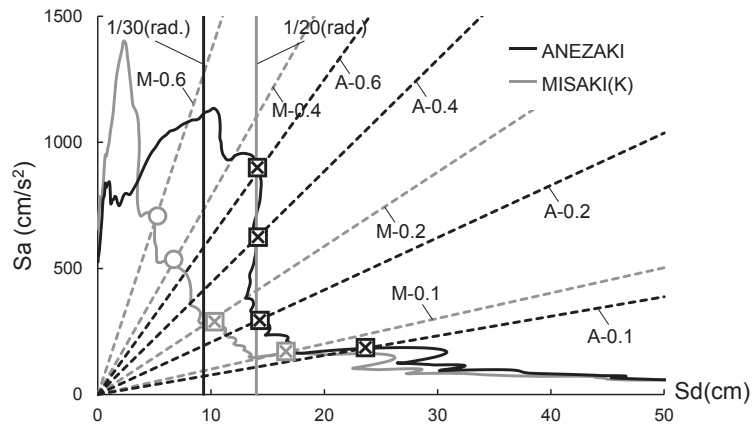

(b) Site class 2 (ANEZAKI, MISAKI(K))

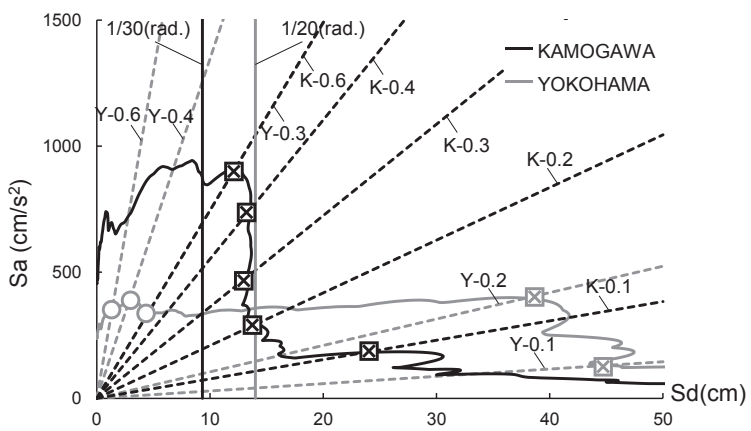

(d) Site class 3 (KAMOGAWA, YOKOHAMA)

Fig.10 $S_{a}-S_{d}$ curve and response periods

を、等価周期 $T_{e q}$ を用いた(18)式より算定し、破線で示す。さらに、 $S_{a}-S_{d}$ 曲線とベースシア係数 $C_{B}$ ごとの $S_{a} / S_{d}$ の破線が交差してい る所のうち、限界層間変形角 $R_{u}$ より小さい最大層間変形角を示した ものを○で、限界層間変形角 $R_{u}$ 以上の最大層間変形角を示したもの を×で示す。

$$
\frac{S_{a}}{S_{d}}=\left(\frac{2 \pi}{T_{e q}}\right)^{2}
$$

1 種地盤（横須賀、鎌倉）の $S_{a}-S_{d}$ 曲線はほぼ同じ形状を示した。 また、 $S_{a}-S_{d}$ 曲線とベースシア係数 $C_{B}$ が 0.1 における $S_{a} / S_{d}$ の交点 の值が限界層間変形角 $R_{u}(=1 / 30(\mathrm{rad})$.$) を超えたが、ベースシア$ 係数 $C_{B}$ が 0.2 以上の場合では、限界層間変形角 $R_{u}$ 以下となった。

2 種地盤の三崎（神奈川）の $S_{a}-S_{d}$ 曲線は、1 種地盤の $S_{a}-S_{d}$ 曲 線とよく類似しており、 $S_{a} / S_{d}$ の交点の值もべースシア係数 $C_{B}$ が 0.4 以上の場合では、限界層間変形角 $R_{u}$ 以下となった。また、 2 種地 盤の川崎、姉崎の $S_{a}-S_{d}$ 曲線は、ベースシア係数 $C_{B}$ の值を 0.6 とし ても $S_{a} / S_{d}$ の交点の值が小さくならず、限界層間変形角 $R_{u}$ 以上の值 を示した。一方、 2 種地盤の厚木の $S_{a}-S_{d}$ 曲線は、ベースシア係数 $C_{B}$ が 0.4 の場合では $S_{a} / S_{d}$ の交点の值が限界層間変形角 $R_{u}$ を超え ているが、ベースシア係数 $C_{B}$ が 0.6 の場合では限界層間変形角 $R_{u}$ 以下となった。なお、姉崎においては、ベースシア係数 $C_{B}$ を 0.2 、 0.4、0.6 と大きくしても $S_{a} / S_{d}$ の交点の位置が変わらず、応答がほ ぼ同じ值を示し、ベースシア係数 $C_{B}$ が 0.6 の場合でも変形角 $1 / 20$ （rad.）を超える結果となった。

3 種地盤においても同様であり、横浜の $S_{a}-S_{d}$ 曲線では、ベース
シア係数 $C_{B}$ が $0.1 、 0.2$ の時における $S_{a} / S_{d}$ の交点の值は限界層間 変形角 $R_{u}$ を超えるが、ベースシア係数 $C_{B}$ を 0.3 とすると $S_{a} / S_{d}$ の 交点の值が限界層間変形角 $R_{u}$ 以下となった。一方、鴨川の $S_{a}-S_{d}$ 曲 線は、 2 種地盤の姉崎とよく似ており、ベースシア係数 $C_{B}$ が 0.6 の 場合においても $S_{a} / S_{d}$ の交点の值が限界層間変形角 $R_{u}$ 以上の值を 示した。

上記のように、同じ地盤種別（2 種地盤、3 種地盤）でも、ベース シア係数 $C_{B}$ の值を大きくしても応答が小さくなりにくい解析地点 (ないし、ベースシア係数 $C_{B}$ の值が小さくても応答が大幅に小さく なる解析地点）が生じる傾向の概略を、 $S_{a}-S_{d}$ 曲線の形状より掴む ことができる。

木造建物においては、ここで扱った観測地点に関しては 3 種地盤 よりの 2 種地盤と 2 種地盤よりの 3 種地盤において応答が小さくな りにくくなると言え、このような地盤に対しては注意が必要である。 なお、本論文で設定しているスペクトルでは低層に対して限界変 形角 $R_{u}$ を超える厳しい結果となる。このような地震動が実際に襲来 するかどうかについては更なる議論が必要であるが、本論文の 3 種 地盤において、ベースシア係数 $C_{B}$ が $0.1 、 0.2$ の場合では応答が大き いが、ベースシア係数 $C_{B}$ を 0.3 とした時に応答が小さくなるケース があったことは、特定行政庁が指定した著しく軟弱な地域である地 盤の 1 次卓越周期 $T_{1}$ が 0.75 秒以上の 3 種地盤 》〕おける木造建物 において壁量の割り増しを求めている結果と符合している。

\section{4. 地域別比較}

本章では、首都圈 118 力所の地盤の差異による耐震性の比較を検 証するため、3 章の応答解析結果から得られた各解析地点の最大層 


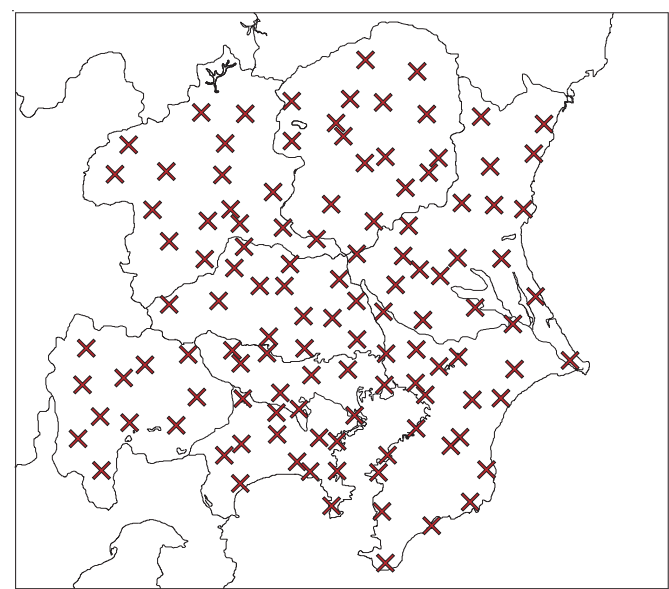

(a) $C_{B}=0.1$

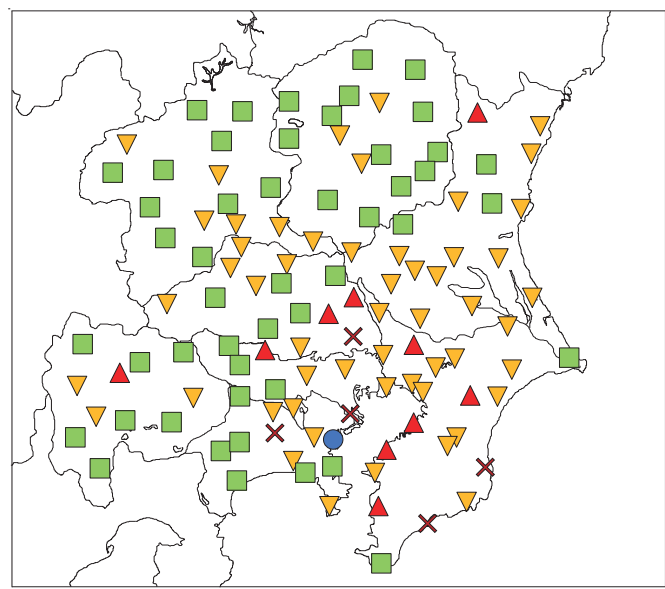

(c) $\mathrm{C}_{\mathrm{B}}=0.4$

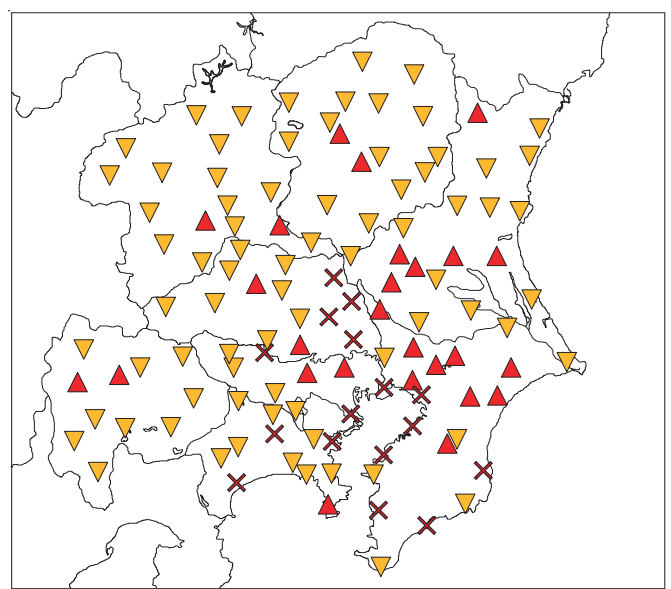

(b) $\mathrm{C}_{\mathrm{B}}=0.2$

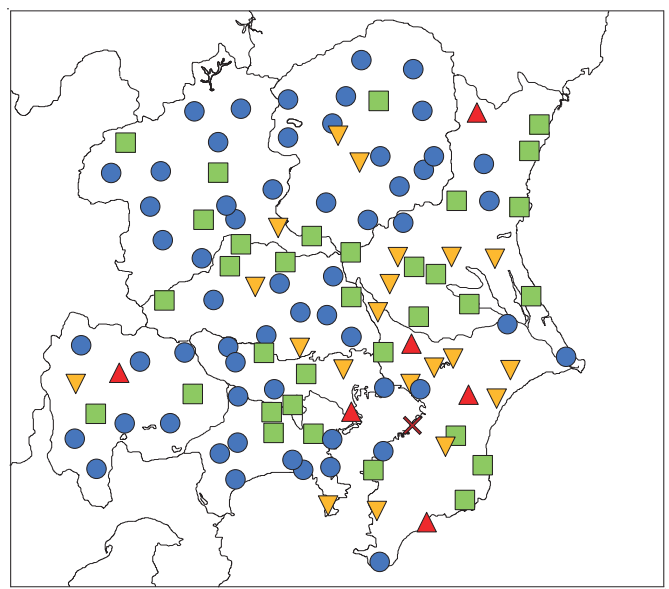

(d) $C_{B}=0.6$

Fig.11 Damage estimation map

間変形角を文献 ${ }^{14)}$ 参考に倒壊、大破、中破、小破、軽微の 5 種類 に分類した災害想定マップを示す。

Fig.11 にベースシア係数 $C_{B}$ ごとの災害想定マップを示す。図中の 記号と想定される被害及び最大層間変形角との関係を Table4 に示 す。なお、Fig.11 はあくまで解析地点における建物の耐震性を示す ものであり、その地域全体での耐震性を示すものではないが、一つ の指標として防災上の資料と成り得よう。

ベースシア係数 $C_{B}$ が 0.1 の場合は、首都圏における全ての解析地 点が変形角 $1 / 20$ (rad.) を超え、倒壊判定となった。ベースシア係数 $C_{B}$ が 0.2 の場合では、ほとんどが変形角 $1 / 30$ (rad.) 以下となり、中 破判定となったが、東京湾沿い、埼玉県東部、千葉県沿岸部の解析 地点では変形角 $1 / 20$ (rad.) を超え倒壞判定となった。ベースシア係 数 $C_{B}$ が $0.4 、 0.6$ の場合では、ほとんどの解析地点が中破〜軽微判定 となった。一方、ベースシア係数 $C_{B}$ を 0.6 まで上げても神奈川県の 川崎、千葉の白井、東金、鴨川、茨城県の大子、山梨県の甲府、は 限界変形角である変形角 $1 / 30$ (rad.) を超え、大破判定となり、千葉 県の姉崎は変形角 $1 / 20$ (rad.) を超え、倒壊判定となった。上記より、 東京都東部、埼玉県東部の解析地点ではベースシア係数 $C_{B}$ が小さい と危険な地域と判定されるが、ベースシア係数 $C_{B}$ が大きければ応答 が小さくなる地域と言える。一方、東京湾沿いと千葉県沿岸部の解 析地点はベースシア係数 $C_{B}$ が大きくても応答は小さくなりにくい 傾向があると言える。また、埼玉県西部、茨城県南部、栃木県、群
Table4 Expected damage

\begin{tabular}{|c|c|c|}
\hline 記号 & 変形角 & 想定 \\
\hline$X$ & $1 / 20 \sim$ & 倒壊 \\
\hline$\Delta$ & $1 / 30 \sim 1 / 20$ & 大破 \\
\hline$\nabla$ & $1 / 60 \sim 1 / 30$ & 中破 \\
\hline$\square$ & $1 / 120 \sim 1 / 60$ & 小破 \\
\hline$\square$ & $\sim 1 / 120$ & 軽微 \\
\hline
\end{tabular}

馬県の解析地点はベースシア係数 $C_{B}$ が小さくても応答が小さくな る。

\section{5. まとめ}

本論文では現行耐震基準による木造軸組構法住宅に対し、首都圈 各地における地盤情報を考慮した地震応答解析を行い、而震性の評 価を行った。また、得られた応答解析結果から防災上の資料として 災害想定マップを示した。

以下に、得られた知見を記す。

(1) ベースシア係数 $C_{B}$ が 0.1 の場合では、首都圈全ての解析地点 
で 1 階の最大層間変形角が変形角 $1 / 20$ (rad. ) を超え、倒壊判 定となったが、ベースシア係数 $C_{B}$ を 0.4 まで大きくすると多 くの解析地点が限界層間変形角である $1 / 30$ ( rad.) 以下の応答 を示した。

(2) 2 種地盤と 3 種地盤の一部の解析地点では、ベースシア係数 $C_{B}$ を 0.6 まで大きくしても最大応答変形角が限界層間変形角 以上となった。

(3) 3 種地盤では、周期の短い領域（約 1 秒未満）で加速度応答ス ペクトル $S_{a}$ の值が小さい解析地点（小田原、横浜、久喜）に おいては、ベースシア係数 $C_{B}$ を 0.3 とすることで限界変形角 以下に応答が留まった。

(4) 木造建物は 3 種地盤よりの 2 種地盤と 2 種地盤よりの 3 種地 盤において、応答が小さくなりにくい傾向がある。

(5) 上記(1)〜 (4)の傾向は、地盤の増幅特性の影響による加速度応 答スペクトル $S_{a}$ の形状の違いから概略を掴むことができる。

(6) 提示した災害想定マップより、最大層間変形角が比較的大き くなる地点は東京湾沿いと千葉県沿岸部に多く分布しており、 最大層間変形角が比較的小さくなる地点は埼玉県西部、茨城 県南部、杤木県、群馬県など北関東に多く分布している。

\section{謝辞}

本研究では、防災科学研究所強震ネットワーク (K-NET) に公開 されている土質データを利用した。また、（株）構造計画研究所の RESP-F3T、MX と鹿嶋俊英氏（建築研究所）のView Wave を使用し た。堀口亮真氏（ポラテック株式会社）には多大なご協力を賜りま した。ここに記し、深く感謝の意を表します。

\section{参考文献}

1) Watanabe M. and Sakai Y. : Investigation of Strong Ground Motions which Caused Heavy Damage to High Strength Wooden Houses, Summaries of Technical Papers of Annual Meeting Architectural Institute of Japan, Structures-II, pp.359-360，2019.7 (in Japanese)

渡部真夕子, 境有紀 : 木造建物の耐力が高いにもかかわらず被害が生じ る地震動の検討, 日本建築学会大会学術講演梗概集, 構造-II, pp.359-360, 2019.7

2) Hiraishi H., Kaneko M. and Hiratsuka T. : Study on Earthquake Response of Buildings Considering Site Amplification Effect, Journal of Structural and Construction Engineering (Transactions of AIJ), Vol.74, No.641, pp. 13031309, 2009.7 (in Japanese)

平石久廣, 金子雅之, 平塚高弘：地盤増幅特性の影響を考慮した建築物 の地震応答予測に関する研究, 日本建築学会構造系論文集, 第 74 巻, 第 641 号, pp.1303-1309, 2009.7

3) Hiraishi H., Izumi H. and Tsumiyama Y. : Seismic Performance of Reinforced Concrete Buildings Designed by Current Seismic Code in Metropolitan Area, Journal of Structural and Construction Engineering (Transactions of AIJ), Vol.81, No.722, pp.769-777, 2016.4 (in Japanese)

平石久廣, 和泉寛幹, 積山㤵: 首都圈における現行基準鉄筋コンクリー 卜造建物の耐震性に関する研究, 日本建築学会構造系論文集, 第 81 巻, 第 722 号, pp.769-777, 2016.4

4) Ode D., Izumi H., Otsuka Y. and Hiraishi H. : Study on Seismic Performance of Reinforced Concrete Low-Rise Buildings on Actual Ground in Metropolitan Area, AIJ Journal of Technology and Design, Vol.24, No.58, pp.1035-1040, 2018.10 (in Japanese)

大出大輔, 和泉寛幹, 大塚悠里，平石久廣 : 首都圈実地盤上における鉄 筋コンクリート造低層建物の耐震性能に関する研究, 日本建築学会技 術報告集, 第 24 巻, 第 58 号, pp.1035-1040, 2018.10

5) Building Research Institute, The Building Center of Japan : Technical
Guidelines for Generating Input Earthquake Motions for Design (Draft), 1992 (in Japanese)

建設省建築研究所，日本建築センター：設計用入力地震動作成手法技術 指針（案）, 1992

6) Hardin, B.O. and Drnevich, V.P. : Shear Modulus and Damping in Soils : Design Equations and Curves, Proc. ASCE, SM7, pp.667-692, 1972

7) Commentary on Structural Regulations of the Building Standard Law of Japan Editorial Committee : 2020nenban Kenchikubutsu no Kouzoukankei Gijutsukijun Kaisetsusho (Commentary on Structural Regulations of the Building Standard Law of Japan 2020 Edition), Official Gazette Cooperation of Japan, 2020(in Japanese)

建築物の構造関係技術基準解説書編集委員会 : 2020 年版建築物の構造 関係技術基準解説書, 全国官報販売協同組合, 2020

8) Housing Production Division, Housing Bureau, Ministry of Land, Infrastructure, Transport and Tourism, Building Research Institute, The Building Center of Japan, Japan Association for Building Research Promotion : 2001nenban Genkaitairyoku Keisanhou no Keisanrei to Sono Kaisetsu (Calculation Example and Explanation of The Limit Strength Calculation 2001 Edition), Kougakutosyo Corporation, 2001 (in Japanese)

国土交通省住宅局建築指導課，国土交通省建築研究所，財団法人日本建 築センター, 社団法人建築振興協会 編集 : 2001 年版限界耐力計算法の 計算例とその解説, 工学図書, 2001

9) Isoda H. and Kawai N. : Hysteresis Model of Walls on Japanese Conventional Construction - Study on Seismic Behavior of Wooden Construction - , Journal of Structural and Construction Engineering (Transactions of AIJ), No.616, pp.157-163, 2007.6 (in Japanese)

五十田博, 河合直人 : 木造軸組構法住宅に用いる壁の復元力特性モデル 一木造建物の地震時挙動に関する研究一, 日本建築学会構造系論文集, 第 616 号, pp.157-163, 2007.6

10) Japan Building Disaster Prevention Association : Guideline of Damage Degree Classification Criterion and Restoration technology on Earthquake Disaster Building, Official Gazette Cooperation of Japan , 2015 (in Japanese) 日本建築防災協会 : 再使用の可能性を判定し、復旧寸るための震災建築 物の被災度区分判定基準および復旧技術指針，全国官報販売協同組合， 2015

11) Ozawa A. and Isoda H. : Study on Recent Seismic Diagnosis and Cost for Retrofit in Wooden Houses, Summaries of Technical Papers of Annual Meeting Architectural Institute of Japan, Structures-II, pp.525-526, 2010.7 (in Japanese) 小澤亮公, 五十田博 : 木造住宅の耐震診断と補強費用の現状に関する一 考察, 日本建築学会大会学術講演梗概集, 構造-II, pp.525-526, 2010.7

12) Nagaoka S. and Isoda H. : Establishment and Accuracy of Seismic Response Estimation of Wooden Houses by The Equivalent Linearization Technique, Journal of JAEE, Vol.13, No.3, pp.1-13, 2013 (in Japanese) 長岡修，五十田博 : 等価線形化法による木造住宅の地震時応答推定とそ の精度, 日本地震工学会論文集, 第 13 巻, 第 3 号, pp.1-13, 2013

13) Isoda H., Filiatrault A. and Folz B. : A Case Study of Seismic Modeling and Analytical Study on Woodframe Buildings in California - Analytical Study on Seismic Behavior of Wooden Construction -, Journal of Structural and Construction Engineering (Transactions of AIJ), No.563, pp.115-121, 2003.1 (in Japanese)

五十田博, アンドレフィリアトロ，ブライアンフォルツ：カリフォルニ ア地域の建物を対象とした木造住宅の振動解析モデルの一事例 : 木造建 物の地震時挙動に対寸る解析的研究, 日本建築学会構造系論文集, 第 563 号, pp.115-121, 2003.1

14) Idota H., Mineoka S., Umemura H. and Mori Y. : Relationship Between Seismic Capacity Grade and Damage for Post and Beam Wooden Structures - A Study on Decision-Making Tools for Promoting Aseismic Reinforcement of Old Wooden Houses (Part 1) - , Journal of Structural and Construction Engineering (Transactions of AIJ), No.612, pp. 125-132, 2007.2 (in Japanese) 井戸田秀樹, 嶺岡慎悟, 梅村恒, 森保宏 : 在来軸組木造住宅における一 般耐震診断の評点と損傷度の関係 耐震改修促進のための意思決定支援 ツールに関する検討（その1）, 日本建築学会構造系論文集, 第 612 号, pp.125-132, 2007.2 


\title{
STUDY ON SEISMIC PERFORMANCE OF JAPANESE CONVENTIONAL WOODEN HOUSES IN METROPOLITAN AREA IN JAPAN
}

\author{
Yuri OTSUKA ${ }^{* 1}$, Hiroshi ISODA ${ }^{* 2}$ and Hisahiro HIRAISHI ${ }^{* 3}$ \\ ${ }^{* 1}$ Building Research Institute, Dr.Eng. \\ * 2 Prof., Research Institute for Sustainable Humanosphere, Kyoto Univ., Dr.Eng. \\ *3 Prof. Emer., Dept. of Architecture, School of Science and Technology, Meiji Univ., Dr.Eng. / \\ Visiting Research Fellow, Building Research Institute
}

The response analysis was conducted considering the site amplification effect on Japanese conventional wooden houses in metropolitan area in this paper. Then, the general tendency of seismic response of the Japanese conventional wooden houses was investigated from the analytical results. Finally, the wooden houses damage estimation map in the metropolitan area was shown for a disaster prevention material. The major findings obtained in this paper were as follows.

1) If the base shear coefficient was 0.1 , the first story's maximum drift angle exceeded the drift angle of $1 / 20$, judged as collapse at all analytical sites in the metropolitan area. If the base shear coefficient was 0.4 , response drift angles showed values below the safety drift angle $(1 / 30(\mathrm{rad})$.$) judged as severe damage in most sites.$

2) Even if the base shear coefficient was 0.6 , the maximum response drift angle was larger than the safety limit drift angles $(1 / 30(\mathrm{rad})$. at some sites in Site class 2 and Site class 3.

3) In the Site class 3, it might be possibly less than acceptable drift angle even for houses whose base shear coefficient is not so high, if the site acceleration response spectrum is small within the shorter period less than about 1 second.

4) It was not easy for wooden houses to reduce their response at the sites in Site class 2, and the sites judged as Site class 3 closer to Site class 2 .

5) The phenomenal above mentioned in items 1) 4) were possibly understood from the acceleration response spectrum considering the site amplification effect.

6) From the damage estimation map presented in this paper, it may be understood that the maximum response drift angle was large near Tokyo Bay and Chiba's coast and that the sites where the maximum response drift angle was relatively small were the northern Kanto region, such as western Saitama, southern Ibaraki, Tochigi, and Gunma. 